\title{
Caffeic Acid Phenethyl Ester Alleviates Cryodamage to Lung Cancer Cells During Cryopreservation
}

\author{
Ezgi Avsar Abdik \\ Yeditepe University, Department of Genetics and Bioengineering, Istanbul, Turkey
}

\author{
Article History: \\ Received: 2021/06/10 \\ Accepted: $2021 / 09 / 23$ \\ Online: $2021 / 09 / 29$
}

Correspondence to: Ezgi Avşar Abdik e-mail:ezgi.avsar@yeditepe.edu.tr; Phone: +90 (216) 5780619 ; Fax: $+90(216) 5782182$. phenethyl ester (CAPE) is a natural biological compound which is found in propolis extract and possess beneficial effects such as anti-oxidant, antimicrobial, anti-inflammatory. In the current study was to investigate the cryoprotective effects of CAPE on human lung cancer cell line, A549. Firstly, cells were cryopreserved in freezing medium with/without different concentrations of CAPE $(5,10$, and $20 \mu \mathrm{M})$. The cells were frozen slowly and kept in liquid nitrogen for one month. After thawing, the cryoprotective effects of CAPE were determined by cell viability, proliferation, colony formation, and gene expression levels. The results showed that $5 \mu \mathrm{M}$ CAPE supplemented freezing medium significantly increased the viability of post thaw A549 cells. $5 \mu \mathrm{M}$ CAPE treatment significantly increased cell proliferation after 24,48 and $72 \mathrm{~h}$ since thawing compared to control. $10 \mu \mathrm{M}$ CAPE did not significantly affect cell viability compared to control group. Also, $5 \mu \mathrm{M}$ CAPE increa-

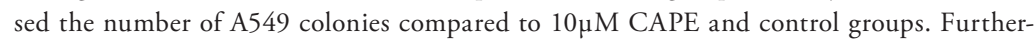
more, markedly larger colonies were noticed in $5 \mu \mathrm{M}$ CAPE group. In addition, $5 \mu \mathrm{M}$ CAPE significantly increased apoptosis and proliferation-related genes, Akt, NFKB and Bcl-2, expression levels compared to $10 \mu \mathrm{M}$ CAPE and control groups. CAPE may be a potential cryoprotective agent for relieving cryodamage during cryopreservation.

Keywords:

Cryopreservation; Cryoprotective agents; CAPE; Lung cancer cell line; Cell viability

\section{INTRODUCTION}

ryopreservation is a process to preserves viable cells and tissues at very low-temperature conditions for a long period time [1]. Cryopreservation of various cell types is important to ease storage of large quantities, transportation and banking for long periods of time [2]. However, production of reactive oxygen species (ROS), osmotic pressure and ice crystals cause irreversible damage the structure and function of cells undergoing the freezing and thawing processes. Under oxidative stress, accumulation of intracellular ROS production leads to the marked reduction in the viability of freeze-thawed cells and trigger apoptotic cell death. In fact, studies have reported that a relationship between ROS and apoptotic cell death and also compounds with antioxidant properties can inhibit apoptosis by acting as ROS scavengers [3].
During cryopreservation process, the formation of ice crystals can be lethal for viable cells. Fast cooling can causes the death of cells due to intracellular ice formation. In the last few decades, researches have focused on optimization of cryopreservation procedures and the addition of cryoprotective agents (CPAs) to protect cells overcoming freeze-thaw stress. CPAs should have some features such as being able to easily penetrate into the cells and possess low toxicity [4]. Dimethyl sulfoxide (DMSO) is commonly used as CPAs for cryopreservation process, however, it may not be appropriate for cryopreservation of cells are used in clinical practice due to its cytotoxicity. Therefore, there is a need to develop alternatives to reduce the toxic effects of DMSO [5],[6].

Caffeic Acid Phenethyl Ester (CAPE) is a biologically active component existing in propolis extract 
which is found in the base of the honeybee hives. CAPE is a structurally related to flavonoids and has polyphenolic structures that contains hydroxyl groups. It is a non-toxic and lipophilic antioxidant. Due to its structural features, CAPE exerts numerous beneficial effects such as anti-inflammatory, immunomodulatory, and anti-oxidant [7],[8]. CAPE completely inhibits the ROS production due to its free radical scavenging and anti-oxidant activity [9],[10]. It has been determined that CAPE has no detrimental effect on healthy cells [11]. Furthermore, several studies showed that CAPE plays a protective role to prevent cells from undergoing apoptosis. CAPE can exert anti-apoptotic properties via inhibiting ROS production and caspase activation [11]-[13].

This study was to determine the protective effects of CAPE on human lung carcinoma cell line, A549, after freezing and thawing process during cryopreservation.

\section{MATERIALS AND METHODS}

\section{Cell Culture and Reagent}

Non-small cell lung cancer cell line, A549, was purchased from the ATCC (American Type Culture Collection, Rockville, MD). They were cultured in DMEM-High Glucose (Gibco, UK) supplemented with 10\% fetal bovine serum (FBS, Gibco, UK) and 1\% Penicillin/Streptomycin/ Amphotericin (PSA, Gibco, UK) under 5\% CO2, 95\% humidity at $37^{\circ} \mathrm{C}$. Cells were trypsinized and passaged after enough confluency 80\%.

CAPE (\#BCBR2913V, Sigma-Aldrich, USA) was resuspended in DMSO (dimethyl sulfoxide, 1550557, Fisher Scientific, UK) to reach the main stock concentration of $20 \mathrm{mM}$ and kept in $-20^{\circ} \mathrm{C}$.

\section{Cell Freezing, Thawing and Storage}

Freezing and thawing process was performed to show the potential cryoprotective effect of CAPE on lung cancer cell line. Briefly, cells were trypsinized and total cell number were counted using hemocytometer. Cells were divided into four different groups. 1x106 cells from each group were resuspended in $1 \mathrm{~mL}$ cell freezing medium (90\% FBS, 10\% DMSO) with 5, 10 and $20 \mu \mathrm{M}$ CAPE and without (control group, $0 \mu \mathrm{M}$ CAPE). Then they were frozen in a freezing container at $-80^{\circ} \mathrm{C}$. After $24 \mathrm{~h}$ incubation, the cryo-vials were transferred and stored into $196^{\circ} \mathrm{C}$ liquid nitrogen tank. After 30 days storage, the cells were placed in a $37{ }^{\circ} \mathrm{C}$ water bath immediately, rinsed with culture medium to reduce detrimental effect of DMSO and centrifuged. Then, the cell pellet was diluted in growth medium for further experiments.

The schematic representation of the experiment is shown in Fig. 1.

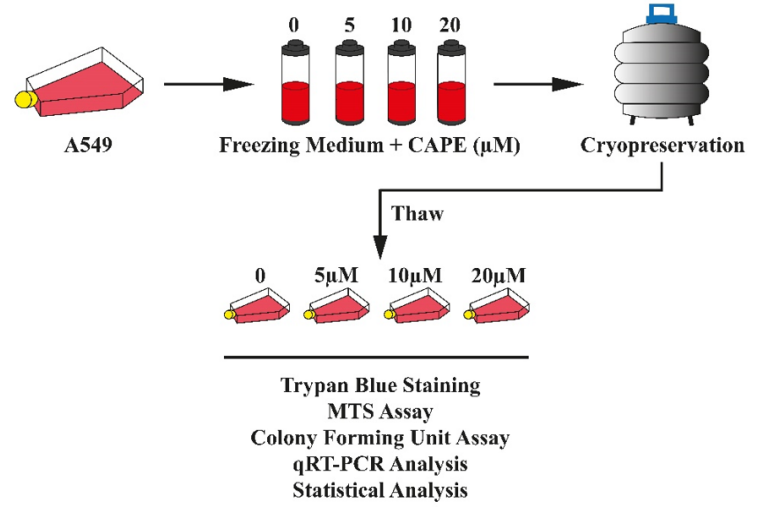

Figure 1. The schematic illustration of the experimental design.

\section{Trypan Blue Staining}

Trypan blue staining (T-8154, Sigma-Aldrich) was performed to assess the cell viability. Briefly, after thawing process, cell suspension were mixed with $0.4 \%$ trypan blue (1:1 ratio) and incubated $5 \mathrm{~min}$ at room temperature (RT). After the incubation, viable/dead cells were counted using a hemocytometer.

\section{MTS Assay}

MTS (3-(4,5-di-methyl-thiazol-2-yl)-5-(3-carboxymethoxyphenyl)-2-(4-sulfo-phenyl)-2H-tetrazolium) assay (CellTiter96 Aqueous One Solution; Promega, Southampton, UK) was conducted to assess the proliferative effects of CAPE concentrations on the cells. Briefly, cells (5x103) were seeded into 96-well plates for 24, 48 and $72 \mathrm{~h}$. After the incubation periods, $10 \mu \mathrm{L}$ MTS solution was added into each wells and incubated for $1 \mathrm{~h}$ at $37^{\circ} \mathrm{C}$ in the dark. The optical density (OD) was read at $495 \mathrm{~nm}$ by using ELISA microplate reader (Biotek, Winooski, VT).

\section{Colony Forming Unit (CFU) Assay}

Colony forming unit assay was used to determine the effects of CAPE concentrations on frozen-thawed cells. Briefly, cells were seeded into 6-well plates (300 cells/well) and medium was changed with fresh growth medium five times for 15 days until colonies were visible. Then, $4 \%$ paraformaldehyde (PFA) was used to fix colonies for $30 \mathrm{~min}$ and they were stained with crystal violet dye for $10 \mathrm{~min}$. After the incubation, colonies were observed and photographed by ZEISS PrimoVert light microscopy system with AxioCam ICc 5 camera.

\section{Quantitative Real Time PCR (qRT-PCR) Analysis}

Changes in proliferation and apoptosis-related gene expression levels were determined by qRT-PCR analysis. Briefly, cells (150x103) were seeded into 6-well plates. After 24h, total RNAs were isolated using High Pure RNA isolation kit (\#11828665001, Roche, USA) and then cDNA was synthesized according to the High Fidelity cDNA synthesis kit (\#05081955001, Roche, USA) protocol. 
A

B
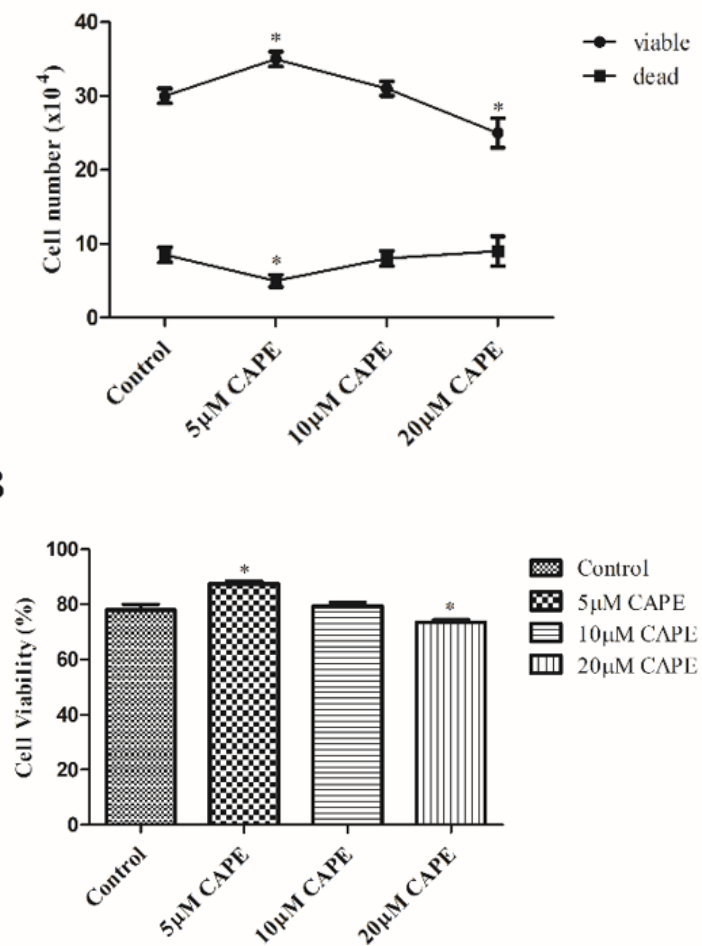

Figure 2. Effects of CAPE concentrations (5, 10 and 20 $\mu \mathrm{M})$ on viability of thawed A549 cells were evaluated using trypan blue staining A. The viable (trypan blue-negative) and dead (trypan blue-positive) cell number after cryopreservation. B. Cell viability (\%) after cryopreservation in 5, 10 and $20 \mu \mathrm{M}$ CAPE. ${ }^{*} \mathrm{P}<0.05$.

mRNA levels of the target genes were determined by qRT-PCR with SYBR Green Master Mix (Thermo-Fisher, USA). $2 \mu \mathrm{L}$ cDNAs, $1 \mu \mathrm{L}$ primers, $5 \mu \mathrm{L}$ SYBR-mix (\#K0221, Fermentas, USA) and $2 \mu \mathrm{L}$ PCR grade distilled water (\#SH30538.02, Hyclone, Utah, USA) in a total volume of $20 \mu \mathrm{l}$ was used for RT-PCR. Primer-BLAST software (National Center for Biotechnology, MD, USA) were used to design AKT, NFKB and BCL-2 primers and Macrogen (Seoul, Korea) synthesized these primers. Data were normalized by a housekeeping gene GAPDH. The CFX96 RT-PCR system was used for RT-PCR experiments (Bio-Rad, Hercules, CA).

\section{Statistical Analysis}

One-way analysis of variance (ANOVA) was used to statistical analysis followed by Tukey's post-hoc test. The data was given as the mean \pm SD. Statistical significance was considered as $\mathrm{P}<0.05$.

\section{RESULTS}

\section{CAPE Protects Lung Cancer Cells in Cryopreservation Process}

The trypan blue staining was used to assess the effects of different CAPE concentrations $(5,10$ and $20 \mu \mathrm{M})$ on the
A

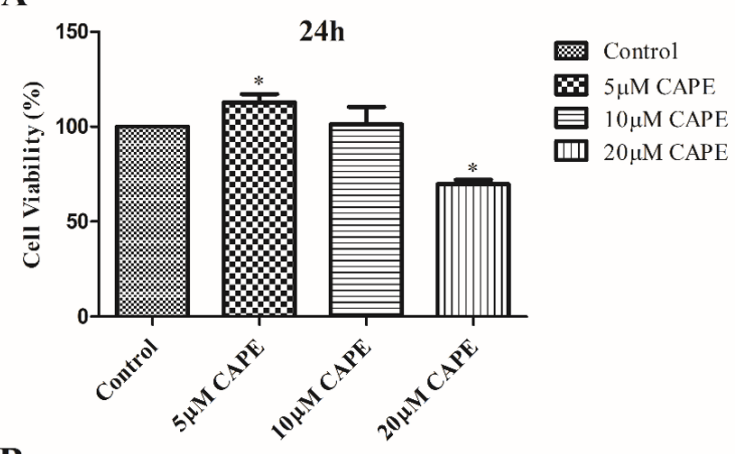

B
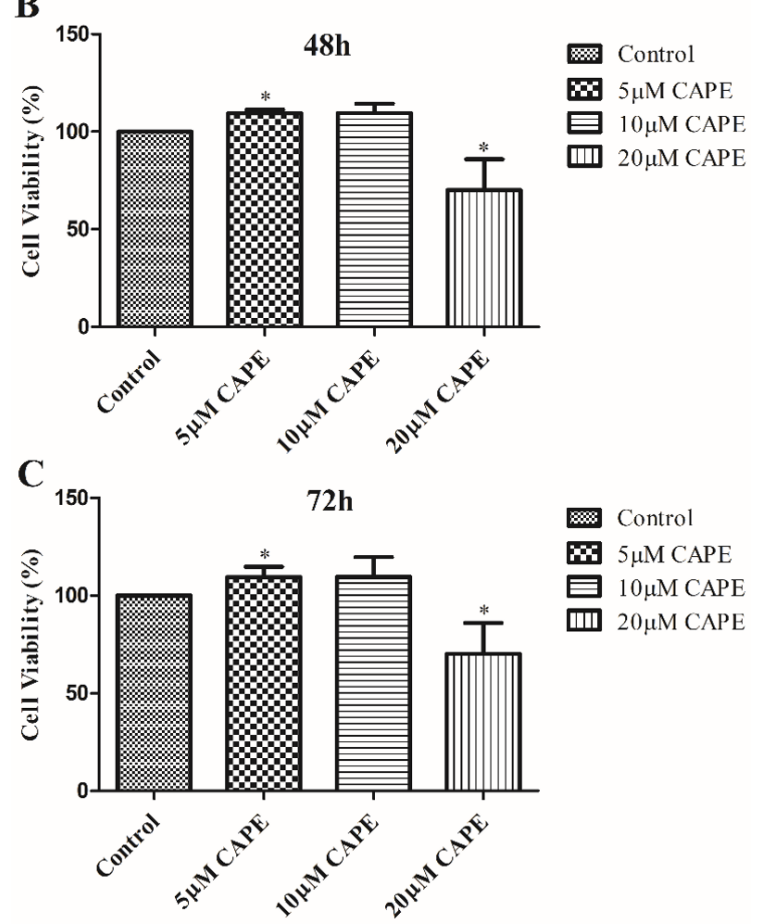

Figure 3. Effects of CAPE concentrations $(5,10$ and $20 \mu \mathrm{M})$ on viability of thawed A549 cells for (A) 24, (B) 48 and (C) 72h were evaluated by MTS assay. ${ }^{*} \mathrm{P}<0.05$.

viability of A549 cells. A dose of $5 \mu \mathrm{M}$ CAPE added to freezing medium significantly increased viable and reduced dead cells (Fig. 2A).

Cryopreservation medium supplemented with $5 \mu \mathrm{M}$ CAPE notably increased the viability of post-thaw A549 cells $(87 \pm 1.5 \%)$. No significant effects was observed in $10 \mu \mathrm{M}$ CAPE supplemented group $(79 \pm 0.7 \%)$ compared to control $(78 \pm 1.3 \%)$, suggesting that $5 \mu \mathrm{M}$ CAPE was selected for further experiment. However, cryopreservation medium supplemented with $20 \mu \mathrm{M}$ CAPE significantly decreased the viability of post-thaw A549 cells (73 $\pm 0.5 \%)$ (Fig. 2B).

\section{CAPE Improves the Proliferation of Lung Cancer Cells in Cryopreservation Process}

MTS assay was conducted to assess the proliferation for 24,48 and $72 \mathrm{~h}$ after thawing process. $5 \mu \mathrm{M}$ CAPE signifi- 
A
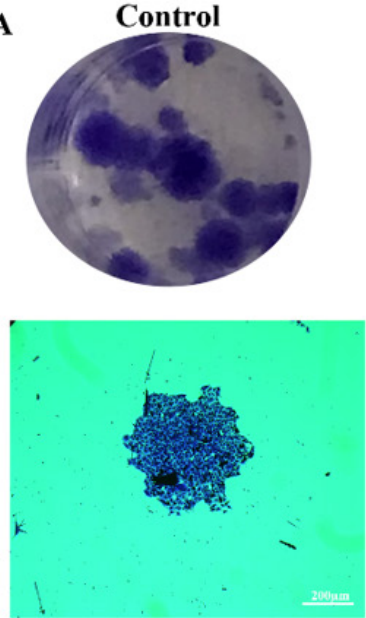

B
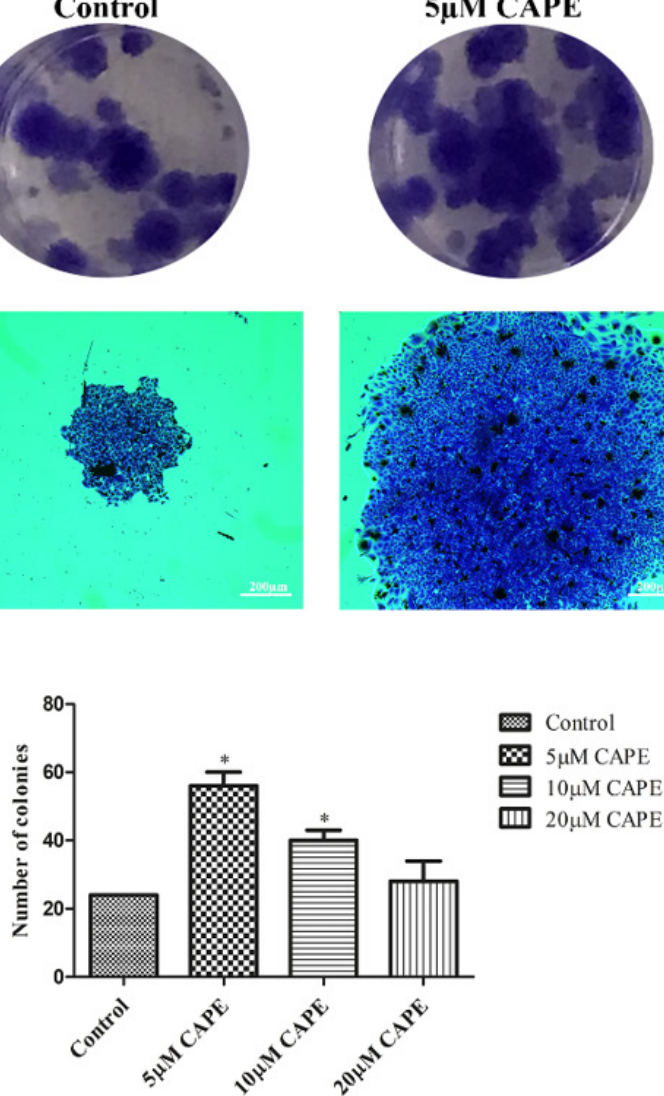

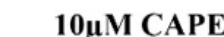
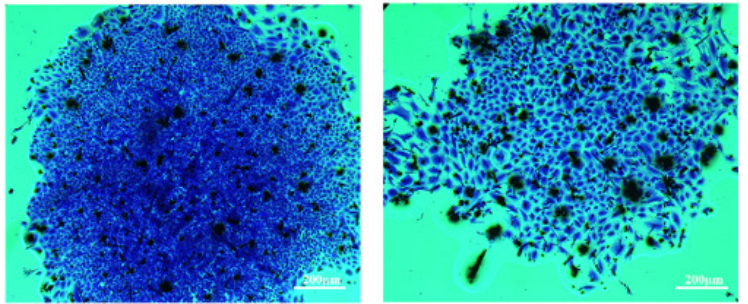

C

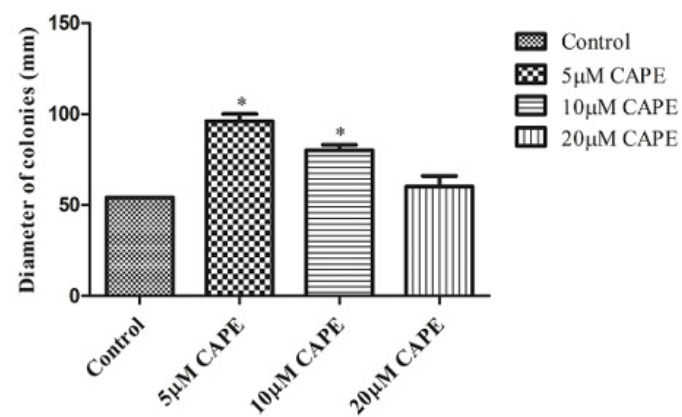

Figure 4. Effects of CAPE concentrations $(5,10$ and $20 \mu \mathrm{M})$ on colony forming ability of thawed A54.9 cells. A. The colony formation ability of A54. cells in each group was assessed by CFU assay. B. Graph shows the number of colonies. C. Graph shows the diameter of colonies. ${ }^{*} \mathrm{P}<0.05$.

cantly increased cell viability to $112 \pm \% 4,109 \pm 1 \%, 118 \pm 5 \%$ after 24,48 and $72 \mathrm{~h}$, respectively. There was no observed any significant changes in the viability of $10 \mu \mathrm{M}$ CAPEsupplemented group while, at the highest CAPE concentration of $20 \mu \mathrm{M}$ significantly decreased the viability of cells after 24,48 and $72 \mathrm{~h}$ after thawing compared to control (Fig. 3).

\section{CAPE Enhances Colony Forming Capacity of Lung Cancer Cells}

CFU assay was assessed the effects of different CAPE concentrations on colony forming capacity of A549 cells after freezing and thawing process. 5 and $10 \mu \mathrm{M}$ CAPE notably increased the number of A549 colonies compared to $20 \mu \mathrm{M}$ CAPE-supplemented and control group. In addition, no significant difference was observed in number of colonies between $20 \mu \mathrm{M}$ CAPE-supplemented and control group. Moreover, dramatically bigger colonies were noticed in 5 and $10 \mu \mathrm{M}$ CAPE-supplemented group. Size of colonies were similar to $20 \mu \mathrm{M}$ CAPE-supplemented and control group (Fig. 4).

\section{CAPE Changes Gene Expression Profiles of Lung Cancer Cells}

qRT-PCR analysis was used to determine the effects of different CAPE concentrations on pro-apoptotic and anti-apoptotic gene expression levels after freezing and thawing process. The addition of $5 \mu \mathrm{M}$ CAPE resulted in a significant upregulation of AKT ( 75.9 fold), NFKB ( 11.6 fold) and Bcl-2 ( 20.2 fold) expression levels. Similarly, $10 \mu \mathrm{M}$ CAPE significantly upregulated AKT ( 46.5 fold), $\mathrm{NF \kappa B}$ ( $\sim 5.4$ fold) and Bcl-2 ( 6.8 fold) gene expression levels. $5 \mu \mathrm{M}$ CAPE supplementation markedly increased gene expression levels compared to $10 \mu \mathrm{M}$ CAPE (Fig. 5).

\section{DISCUSSION}

Cryopreservation is a crucial process to preserve viable cells, tissues and organs. Cryopreservation of cells is commonly used in numerous fields such as biotechnology, agricultural and medicine. During freezing process, cryodamage may result in reduced cell viability due to the formation of ice crystal [14]. Cryoprotective agents (CPAs) help to alleviate cryodamage and ice crystals by attenuating the water crystallization and improving the viscosity [15],[16]. Glycerol and dimethyl sulfoxide (DMSO) are well known CPAs for several types of cells, however they have some limitations. Glycerol has relatively weak cryoprotective effect while DMSO can exert 
A

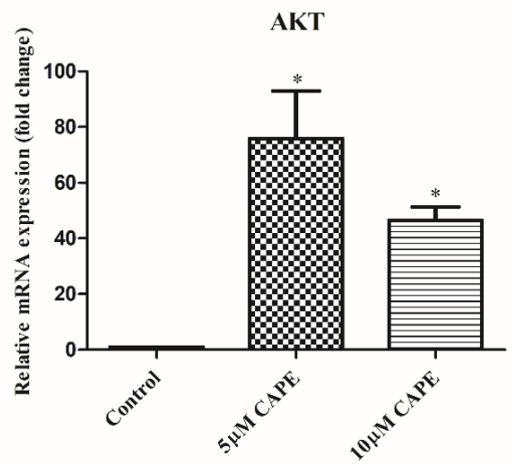

B

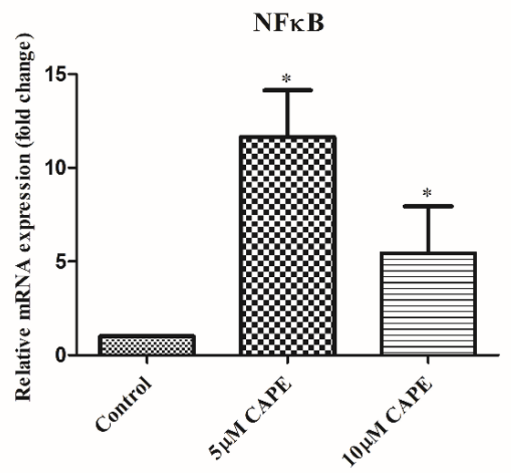

C

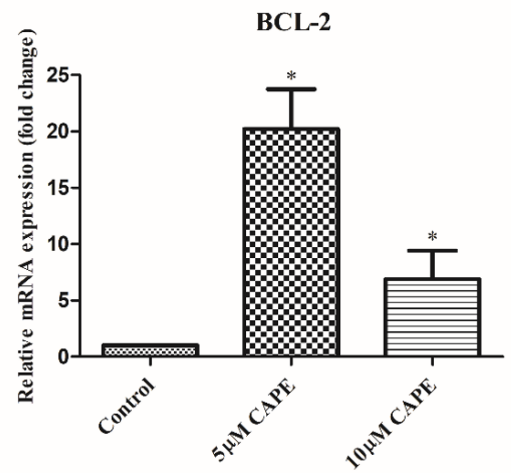

Figure 5. Effects of CAPE concentrations ( 5 and $10 \mu \mathrm{M}$ ) on proliferation and apoptosis related gene expression levels (A) AKT, (B) NFKB and (C) BCL-2 of thawed A549 cells. AKT: Protein kinase B, NFKB: Nuclear factor kappa B, BCL2: B-cell lymphoma 2. ${ }^{*} \mathrm{P}<0.05$.

cytotoxic effect and needs to be quickly removed after thawing process [17]. Recent studies mainly focused on two approaches: reducing DMSO concentration and replacing it with more effective and non-toxic agents.

The cryopreservation increases the cellular ROS production [18]. The excessive ROS production induces oxidative stress and impairs the structure, function and viability of cells [19]. Also, increased ROS levels induce cytochrome $\mathrm{C}$ release from mitochondria to cytosol via stimulation of mitochondrial membrane permeability transition (MMPT), thereby triggering apoptosis [20]. Furthermore, when abnormal changes occur in physiological conditions, cells begin to reuse their components to produce energy and the- reby autophagic cell death is triggered [21]. Non-toxic and effective CPA supplementation in freezing medium to inhibit oxidative stress and apoptosis, significantly improves cryopreservation process [22].

CAPE, a natural phenolic compound, is found in propolis and has beneficial effects such as antioxidant, antimicrobial and immunomodulatory. CAPE is an ester form and a derivative of caffeic acid. Due to its structural properties, CAPE presents high biological activity and able to easily cross the cell membranes than caffeic acid [23]. Several studies have examined the use of caffeic acid on cryopreservation process [24],[25]. Cryopreservation elevates apoptotic biomarkers such as membrane permeability and caspase activation [26]. CAPE can exert anti-apoptotic properties via inhibiting ROS production and caspase activation [11],[12]. However, the effects of CAPE on cryopreservation of cells are still largely unknown, it needs to be elucidated.

This study was evaluated the potential cryoprotective efficiency of CAPE on lung cancer cells. These results showed that the addition of CAPE to the freezing medium significantly increases the viability of A549 cells after cryopreservation process. The number of viable A549 cells was markedly elevated by CAPE included cryopreservation medium. The viability of post-thaw A549 in $5 \mu \mathrm{M}$ CAPEsupplemented group was significantly higher than 10 and $20 \mu \mathrm{M}$ CAPE-supplemented and control groups. $5 \mu \mathrm{M} \mathrm{CAPE}$ showed to protect A549 cells to against apoptosis. Moreover, $5 \mu \mathrm{M}$ CAPE was significantly increased the proliferation rates of the cells for 24,48 and $72 \mathrm{~h}$. The proliferation rates of the cells treated with $10 \mu \mathrm{M}$ CAPE was similar to control group. CFU results also supported the cell viability analysis. $5 \mu \mathrm{M}$ CAPE-supplemented group was shown significantly increased colony formation capacity of cells. However, there was no significant change in CFU assay of $10 \mu \mathrm{M}$ and $20 \mu \mathrm{M}$ CAPE-supplemented group, indicating that $5 \mu \mathrm{M}$ CAPE has shown to have a better effect in protecting cell functions. Similar to these results, Li et. al reported that CAPE significantly increase the viability of cells and colony formation capacity [27].

It is known that cryopreservation process change the gene expression profiles of cells [28]. PI3K/AKT signaling leads to the inhibition of apoptotic signaling cascade, which is associated with the production of reactive oxygen species, caspase activation [29]. Akt, a serine/threonine kinase, has a pivotal role in survival and proliferation of cells [30]. The agents with anti-oxidant properties was shown to increase the Akt expression level during cryopreservation [31].

Transcription factor NFkB is a downstream target of Akt and activation of NFKB promote cell survival [32]. Moreover, $\mathrm{Bcl}-2$ family members are major role in regulating 
apoptosis and cell survival. Upregulation of anti-apoptotic Bcl-2 inhibits apoptosis and promotes cell survival [33]. qRT-PCR analysis revealed that CAPE treatment upregulates the proliferation related gene expression, Akt, NFkB, and anti-apoptotic gene expression level, Bcl-2, in A549 cells. The AKT, NFKB and BCL-2 levels were shown to be increased in A549 cell after freezing and thawing process with 5 and $10 \mu \mathrm{M}$ CAPE. However, $5 \mu \mathrm{M}$ CAPE supplementation has shown significantly upregulated these genes compared to $10 \mu \mathrm{M}$ CAPE. In consistent with these results, previous studies have reported that CAPE reduce apoptotic cell death and induce cell proliferation [34]-[36].

\section{CONCLUSION}

Taken together, the addition of CAPE to the freezing medium increased the viability, colony formation capacity and proliferation related gene expression of post thaw A549 cells. CAPE, a natural compound, may be a promising candidate as a cryoprotective agent for protection of cells from cryodamage and storage of cells without loss of their viability for long periods of time. Further studies are required to understand the underlying the protective mechanisms of CAPE at molecular level and its role in cellular metabolism during cryopreservation process. Additionally, the protective effects of CAPE should be investigated after long term cryopreservation.

\section{ACKNOWLEDGEMENTS}

This study was supported by Yeditepe University.

\section{CONFLICT OF INTEREST}

Authors approve that to the best of their knowledge, there is not any conflict of interest or common interest with an institution/organization or a person that may affect the review process of the paper.

\section{References}

1. Pegg DE. Principles of cryopreservation. In: Cryopreservation and Freeze-Drying Protocols. Springer, (2015) 3-19.

2. Gonda $K$, Shigeura $T$, Sato $T$, Matsumoto D, Suga $H$, Inoue K, Aoi N, Kato H, Sato K, Murase S, Koshima I, Yoshimura, K. Preserved proliferative capacity and multipotency of human adipose-derived stem cells after long-term cryopreservation. Plastic and reconstructive surgery 121 (2008) 401-410.

3. Nunes VA, Gozzo AJ, Cruz-Silva I, Juliano MA, Viel TA, Godinho RO, Meirelles FV, Sampaio MU, Sampaio CAM, Araujo MS. Vitamin E prevents cell death induced by mild oxidative stress in chicken skeletal muscle cells. Comparative
Biochemistry and Physiology Part C: Toxicology \& Pharmacology 141 (2005) 225-240.

4. Joshi A. A review and application of cryoprotectant: The science of cryonics. PharmaTutor 4 (2016) 12-18.

5. Luzar A, Chandler D. Structure and hydrogen bond dynamics of water--dimethyl sulfoxide mixtures by computer simulations. The Journal of chemical physics 98 (1993) 8160-8173.

6. Hornberger K, Yu G, McKenna D, Hubel A. Cryopreservation of hematopoietic stem cells: emerging assays, cryoprotectant agents, and technology to improve outcomes. Transfusion Medicine and Hemotherapy 46 (2019) 188-196.

7. Borrelli F, Maffia P, Pinto L, Ianaro A, Russo A, Capasso F, Ialenti A. Phytochemical compounds involved in the antiinflammatory effect of propolis extract. Fitoterapia 73 (2002) S53--S63.

8. Koltuksuz U, Irmak MK, Karaman A, Uz E, Var A, Ozyurt $\mathrm{H}$, Akyol O. Testicular nitric oxide levels after unilateral testicular torsion/detorsion in rats pretreated with caffeic acid phenethyl ester. Urological research 28 (2000) 360363.

9. Son S, Lewis BA. Free radical scavenging and antioxidative activity of caffeic acid amide and ester analogues: Structure- activity relationship. Journal of agricultural and food chemistry 50 (2002) 468-472.

10. Zheng Z, Yenari MA. Post-ischemic inflammation: molecular mechanisms and therapeutic implications. Neurological research 26 (2004) 884-892.

11. Guney M, Oral B, Karahan N, Mungan T. Protective effect of caffeic acid phenethyl ester (CAPE) on fluorideinduced oxidative stress and apoptosis in rat endometrium. Environmental toxicology and pharmacology 24 (2007) 8691.

12. Parlakpinar $H$, Sahna E, Acet A, Mizrak B, Polat Al. Protective effect of caffeic acid phenethyl ester (CAPE) on myocardial ischemia--reperfusion-induced apoptotic cell death. Toxicology 209 (2005) 1-14.

13. Amodio R, De Ruvo C, Di Matteo V, Poggi A, Di Santo A, Martelli N, Lorenzet R, Rotilio D, Cacchio M, Esposito E. Caffeic acid phenethyl ester blocks apoptosis induced by low potassium in cerebellar granule cells. International journal of developmental neuroscience 21 (2003) 379-389.

14. Isildar B, Ozkan S, Oncul M, Baslar Z, Kaleli S, Tasyurekli M, Koyuturk M. Comparison of different cryopreservation protocols for human umbilical cord tissue as source of mesenchymal stem cells. Acta histochemica 121 (2019) 361-367.

15. Ninagawa T, Eguchi A, Kawamura Y, Konishi T, Narumi A. A study on ice crystal formation behavior at intracellular freezing of plant cells using a high-speed camera. Cryobiology 73 (2016) 20-29.

16. Mazur P. Kinetics of water loss from cells at subzero temperatures and the likelihood of intracellular freezing. The Journal of general physiology 47 (1963) 347-369.

17. Matsumura K, Hyon S-H. Polyampholytes as low toxic efficient cryoprotective agents with antifreeze protein properties. Biomaterials 30 (2009) 4842-4849.

18. Aliakbari F, Gilani MAS, Amidi F, Baazm M, Korouji M, Izadyar $F$, Yazdekhasti $H$, Abbasi M. Improving the efficacy of cryopreservation of spermatogonia stem cells by antioxidant supplements. Cellular Reprogramming (Formerly" Cloning and Stem Cells") 18 (2016) 87-95. 
19. Shaban S, El-Husseny MWA, Abushouk Al, Salem AMA Mamdouh M, Abdel-Daim MM. Effects of antioxidant supplements on the survival and differentiation of stem cells. Oxidative Medicine and Cellular Longevity 2017 (2017).

20. Bugger $\mathrm{H}$, Pfeil K. Mitochondrial ROS in myocardial ischemia reperfusion and remodeling. Biochimica et Biophysica Acta (BBA)-Molecular Basis of Disease 1866 (2020) 165768.

21. Singh $R$, Cuervo AM. Autophagy in the cellular energetic balance. Cell metabolism 13 (2011) 495-504.

22. Feng T-Y, Li Q, Ren F, Xi H-M, Lv D-L, Li Y, Hu J-H. Melatonin Protects Goat Spermatogonial Stem Cells against Oxidative Damage during Cryopreservation by Improving Antioxidant Capacity and Inhibiting Mitochondrial Apoptosis Pathway. Oxidative Medicine and Cellular Longevity 2020 (2020).

23. Song YS, Park E-H, Hur GM, Ryu YS, Lee YS, Lee JY, Kim $Y M$, Jin C. Caffeic acid phenethyl ester inhibits nitric oxide synthase gene expression and enzyme activity. Cancer letters 175 (2002) 53-61.

24. Mahdi NS, Azarbani F, Pirnia A, Abbaszadeh A, Gholami M. The Effect of Caffeic Acid on Spermatogonial Stem Cell-type A Cryopreservation. Reports of Biochemistry \& Molecular Biology 7 (2018) 85.

25. Soleimanzadeh A, Talavi N, Yourdshahi VS, Bucak MN. Caffeic acid improves microscopic sperm parameters and antioxidant status of buffalo (Bubalus bubalis) bull semen following freeze-thawing process. Cryobiology 95 (2020) 29-35.

26. Balao da Silva CM, Macias-Garcia B, Miró-Morán A, González-Fernández L, Morillo-Rodriguez A, OrtegaFerrusola C, Gallardo-Bolaños JM, Stilwell G, Tapia JA, Peña FJ. Melatonin reduces lipid peroxidation and apoptotic-like changes in stallion spermatozoa. Journal of pineal research 51 (2011) 172-179.

27. Liu Y, Zhang B, Zhang J, Wang S, Yao H, He L, Chen L, Yue W, Li Y, Pei X. CAPE promotes the expansion of human umbilical cord blood-derived hematopoietic stem and progenitor cells in vitro. Science China Life Sciences 57 (2014) 188-194.

28. Çalışkan M, Pritchard JK, Ober C, Gilad Y. The effect of freeze-thaw cycles on gene expression levels in lymphoblastoid cell lines. PloS one 9 (2014) e107166.

29. Koppers AJ, Mitchell LA, Wang P, Lin M, Aitken RJ. Phosphoinositide 3-kinase signalling pathway involvement in a truncated apoptotic cascade associated with motility loss and oxidative DNA damage in human spermatozoa. Biochemical Journal 436 (2011) 687-698.

30. Downward J. PI 3-kinase, Akt and cell survival. In: Seminars in Cell \& Developmental Biology. Vol 15 (2004) 177-182.

31. Najafi A, Adutwum E, Yari A, Salehi E, Mikaeili S, Dashtestani F, Abolhassani F, Rashki L, Shiasi S, Asadi E. Melatonin affects membrane integrity, intracellular reactive oxygen species, caspase 3 activity and AKT phosphorylation in frozen thawed human sperm. Cell and tissue research 372 (2018) 149-159.

32. Fahy BN, Schlieman M, Virudachalam S, Bold RJ. AKT inhibition is associated with chemosensitisation in the pancreatic cancer cell line MIA-PaCa-2. British journal of cancer 89 (2003) 391-397.

33. Braun F, de Carné Trécesson S, Bertin-Ciftci J, Juin P. Protect and serve: $\mathrm{Bcl}-2$ proteins as guardians and rulers of cancer cell survival. Cell Cycle 12 (2013) 2937-2947.

34. Uz E, Söğüt S, Şahin Ş, Var A, Ozyurt H, Güleç M, Akyol O. The protective role of caffeic acid phenethyl ester (CAPE) on testicular tissue after testicular torsion and detorsion. World journal of urology 20 (2002) 264-270.

35. Dilber $Y$, Inan $S$, Ercan GA, Sencan A. The role of CAPE in $\mathrm{PI} 3 \mathrm{~K} / \mathrm{AKT} / \mathrm{mTOR}$ activation and oxidative stress on testis torsion. Acta histochemica 118 (2016) 31-37.

36. Tolba MF, Omar HA, Azab SS, Khalifa AE, Abdel-Naim AB, Abdel-Rahman SZ. Caffeic acid phenethyl ester: a review of its antioxidant activity, protective effects against ischemiareperfusion injury and drug adverse reactions. Critical reviews in food science and nutrition 56 (2016) 2183-2190. 